\title{
Farming practices and the respiratory health risks of swine confinement buildings
}

\author{
Y. Cormier, E. Israël-Assayag, G. Racine, C. Duchaine
}

\begin{abstract}
Farming practices and the respiratory health risks of swine confinement buildings. Y. Cormier, E. Israël-Assayag, G. Racine, C. Duchaine. (C)ERS Journals Ltd 2000.

ABSTRACT: This study investigated whether clean swine confinement buildings (SCB) are less harmful to the respiratory system than older and dirtier facilities.

Eight healthy volunteers were exposed for $4 \mathrm{~h}$, at 1 week intervals, to eight SCB representing the widest possible range of cleanliness. Each volunteer and a technician rated the SCB for cleanliness from 1-10, 1 being the cleanest possible. Airborne dust, bacteria, endotoxin levels, molds, and ammonia were measured. For each volunteer measured, before and after each exposure, forced expiratory flows (forced expiratory volume in one second (FEV1), and forced vital capacity), white cells in nasal wash and venous blood, and nasal lavage levels of interleukin (IL)-8 and serum levels of IL-6. A methacholine challenge was obtained at baseline and following each exposure.

Cleanliness scores ranged $1.5-8.25$. Mean airborne levels were: dust $3.54 \mathrm{mg} \cdot \mathrm{m}^{-3}$ bacteria $4.25 \times 10^{5} \mathrm{CFU} \cdot \mathrm{m}^{-3}$; endotoxins $404 \mathrm{EU} \cdot \mathrm{m}^{-3}$; molds $883 \mathrm{CFU} \cdot \mathrm{m}^{-3}$; ammonia 20.7 parts per million (ppm). Expiratory flows decreased after exposure (FEV1 from $4.8 \pm 0.7$ to $4.4 \pm 0.7, p<0.001)$, neutrophils in the nasal wash and white blood cells increased $\left(28.5 \pm 37\right.$ to $424 \pm 207 \times 10^{3}, 5.4 \pm 1.0$ to $7.4 \pm 1.7 \times 10^{9}$ cells $\mathrm{mL}^{-1}$ respectively), IL-8 increased from $158 \pm 311$ to $2679 \pm 639 \mathrm{pg} \cdot \mathrm{mL}^{-1}$, IL-6 from $0.15 \pm 0.26$ to $2.34 \pm 0.92$ $\mathrm{pg} \cdot \mathrm{mL}^{-1},(\mathbf{p}<0.001)$. All SCB were similarly harmful.

In conclusion, modern farming has not succeeded in making swine confinement buildings inoffensive to exposed subjects.

Eur Respir J 2000; 15: 560-565.
\end{abstract}

Unité de Recherche, Centre de Pneumologie, Université et Hôpital Laval, SteFoy, Québec, Canada.

Correspondence: Y. Cormier Hôpital Laval

2725 Chemin Ste-Foy

Ste-Foy, Québec

Canada G1V 4G5

Fax: 14186564762

Keywords: Air contamination airways

inflammation

Received: April 121999

Accepted after revision November 241999

This study was supported with grants from the Respiratory Health Network of Centers of Excellence (RHNCE), Canada and l'Institut de Recherche en Santé et Sécurite du Travail (IRSST) du Québec.
Exposure to swine confinement buildings (SCB) constitutes a respiratory health hazard to exposed individuals [1-3]. Swine building workers have a high prevalence of chronic bronchitis and airway hyperreactivity [4-7]. Chronic exposure to this environment causes airway inflammation in most people [8]. Naive healthy subjects exposed for a short period of time develop an acute toxic response manifested by an increase in airway responsiveness and in the number of neutrophils and the levels of pro-inflammatory cytokines in the peripheral blood, the nasal passages, and the lungs [9-13].

The air in swine confinement buildings contains a variety of pollutants that can account for the health effects observed. These include micro-organisms with their endotoxins, gases $\left(\mathrm{NH}_{3}, \mathrm{SO}_{2}\right)$, and organic dust (feed, dancers, excrements) [14-17]. It is presently not clear which of these substances or if their combination is responsible for the health effects of SCB. It has recently been shown that nasal filtration did not prevent lung and systemic effects of swine confinement building air, suggesting that small respirable particles are involved [18]. Canola oil spray offers significant protection; the exact effect of spraying oil on the quality of the air in SCB has however not been determined [19].

SCB and swine raising in Quebec (Canada), as for most countries, are not standardized. There is a wide range of building designs and animal raising techniques: different types of feeding, dung collection and elimination, ventilation, heating, cleanliness, etc. Also, the sizes of buildings and the density of pigs raised vary considerably. It is known that the number of microbial contaminants, dust and gas levels vary considerably from one swine building to another $[15,20]$. Before generalizing that all SCB constitute a health risk, it is only fair to verify whether different buildings are similarly hazardous and whether modern designs and production techniques have improved or eliminated the risk to exposed humans. Most importantly, if some SCB are safe, or at least safer, while others are more toxic, it will be important to identify the technology that renders them safe or dangerous and isolate what differences in the air composition are associated with different health effects. This information will be useful for understanding what causes the lung response to SCB air and will aid in the design of better swine raising practices.

The purpose of this study was therefore to verify the effects of short term exposure of healthy volunteers to eight different SCB, buildings selected to represent the widest possible range of different buildings and practices in Quebec: dirtiest to cleanest, modern facilities to poorly designed old units, small to large productions. In parallel to the health effects the authors evaluated environmental variables of each building selected. 


\section{Materials and methods}

\section{Building selection}

Eighteen SCB were visited by one of the authors (Y. Cormier) to select the eight buildings included in this study. A preselection, based on farm description and telephone conversations with some producers, having been made from a large number of facilities provided by the Quebec federation of swine producers. Each swine building selected for the study was visited twice between January 13 and March $5,1997$.

\section{Subjects}

Eight healthy nonsmoking and nonatopic young males (age 23-28) participated in the study; each subject was exposed once to each of the eight facilities, four volunteers per visit. The exposure consisted of spending $4 \mathrm{~h}$ in the $\mathrm{SCB}$, no specific activity was requested; they usually just played cards. All exposures were separated by 1 week. This time sequence was justified by the results of previous studies that showed that the effects of exposure were short lived [9-11]. Volunteers had never been exposed to SCB except for their participation in this study. The protocol was approved by the authors' institution's ethics committee and all participants signed an informed consent form at the beginning of the study.

\section{Physical aspects}

Physical aspects were noted for each SCB at the first visit to that building. Parameters noted were: cleanliness ( $1=$ clean, $10=$ dirty), ventilation, air temperature, building size and number of animals. All eight volunteers and the technician who performed the air samplings separately evaluated each building for cleanliness. Air samples were taken to measure total dust and microbiological counts. Bacteria and molds were counted.

\section{Air sampling and analysis}

All the samples and measures were taken three times: at the beginning, the middle and the end of the 4-h period, except for dust that was sampled continuously for $4 \mathrm{~h}$. Al1 air samplings were taken on a table, $1 \mathrm{~m}$ above the floor. The samplers (AGI filters; Graseby Andersen, Atlanta, GA, USA) were always $\sim 50 \mathrm{~cm}$ from the enclosure. No specific study was performed to evaluate whether the site sampled was the most representative, but visually it was the closest to the sources of contamination and as far away as possible from the doors, windows and other ventilation sources.

For dust measurements, preweighed $37 \mathrm{~mm}$ polyvinyl chloride (PVC) filters (pore size $0.8 \mu \mathrm{m}$ ) housed in closedface cassettes were used with SKC 224-44XR personal sample pumps (Dur-Pro; Brossard, Quebec, Canada) calibrated at $1.5 \mathrm{~L} \cdot \mathrm{min}^{-1}$ (Kurz flow-meter; Instruments Inc., Carmel Valley, CA, USA). The sampling was carried out with the port of entry pointing upwards. Filters were stored in the freezer until the end of the study. Filters were then stored in a drying chamber until constant weight and weighed under controlled atmospheric conditions to avoid rehydration. Control filters were brought to the sampling site, exposed but not subjected to sampling and weighed by the same procedure.

Airborne bacteria were sampled with All-glass impingers-30 (AGI-30; Ace Glass Inc., Vineland, NJ, USA) connected to Gilian Aircon II pumps (Levitt security, Montreal, Canada) at a flow rate of $12.5 \mathrm{~L} \cdot \mathrm{min}^{-1}$ for 16 min, three times during the 4-h period. Pump flow rate was set with a Kurz flow-meter (Instruments Inc.). Sterile AGIs contained $20 \mathrm{~mL}$ of sterile saline water $(0.8 \% \mathrm{NaCl})$ were kept on ice after the sampling. Back at the laboratory (maximum $1 \mathrm{~h}$ after the sampling procedure), the sample volumes were measured (to evaluate evaporation) and completed at $30 \mathrm{~mL}$ with sterile saline water containing $0.15 \%$ Tween 80 (final concentration of $\sim 0.05 \%$ ) and diluted to $10^{-2}$. Nondiluted and diluted samples were plated in triplicate on Trypticase soy agar (TSA) (Difco, Detroit, IL, USA) containing cycloheximide $\left(500 \mathrm{mg} \cdot \mathrm{L}^{-1}\right)$ to avoid mold growth and incubated at $30^{\circ} \mathrm{C}$ for $60 \mathrm{~h}$. Total bacteria were counted at the dilution where the plates showed between 30 300 colonies. As a standard procedure the authors had planned to do control outside samplings, about $1 \mathrm{~km}$ upwind from the $\mathrm{SCB}$, when the outside temperature was above $-4^{\circ} \mathrm{C}$ and compare the levels to the indoor values. Any outside colonies obviously similar to inside ones would be subtracted from the inside values. Since this study was performed during the winter, outside sampling was only carried out once (temperature $=-2^{\circ} \mathrm{C}$ ) and no growth was seen.

AGI-30 samples were used to determine airborne endotoxin concentrations. Samples were kept frozen $\left(-20^{\circ} \mathrm{C}\right)$ in plastic tubes before measurement. Endotoxin was measured with Limulus Amoebocyte Assay (LAL) endpoint chromogenic test (Associates of Cape Cod, Woods Hole, MA, USA). Controls were obtained with sterile saline water containing $0.05 \%$ Tween 80 with which sterile AGI30 samplers were washed for a few minutes. This procedure allowed the measurement of the initial contamination of the samples and material by endotoxins. The control values were subtracted from the sample values. Inhibition and enhancement tests were also performed on the samples.

Airborne molds were sampled with 6-stage Andersen impactors (Grasby Andersen) connected to Gilian Aircon II pumps (Levitt security) at a flow rate of $28.3 \mathrm{~L} \cdot \mathrm{min}^{-1}$ for $2 \mathrm{~min}$, three times during the 4-h period. Pump flow rate was set with a Kurz flow-meter (Instruments Inc.). Andersen samplers were loaded with Rose-bengal agar (Difco) containing chloramphenicoi $\left(50 \mathrm{mg} \cdot \mathrm{L}^{-1}\right)$ to avoid bacterial growth. Dishes were incubated at $30^{\circ} \mathrm{C}$ for 5 days. Molds were identified with microscopic and macroscopic observations. Control sampling was performed as for the bacteria. The control samples were used in comparison with the indoor samples. If similar mold colonies were found outside and inside, the outside level was subtracted. If the population was different, the controls were not used.

The $4 \mathrm{~h}$ ammonia samplings were performed in triplicate. Sulfuric acid pretreated silica gel columns (Dur-Pro) were used with a low flow rate pump $\left(0.15 \mathrm{~L} \cdot \mathrm{min}^{-1}\right)$ calibrated with a SKC UltraFlo Electronic Calibrator (DurPro). Ammonia was analysed by chromatography in a reference laboratory. Control columns were brought to the 
sampling site, exposed to the ambient environment but without pump sampling and were analysed by the same procedure.

\section{Subjects' evaluations}

The volunteers were evaluated at baseline and before and after each exposure. Baseline evaluation included: nasal lavage, venous blood samplings, and methacholine bronchoprovocations. Nasal lavage and blood sampling were carried out at 15:00 h on the first baseline day, the methacholine challenge performed the following morning at 08:00 h. For each subject and each exposure, forced expiratory flows were obtained at 09:00 $\mathrm{h}$ and 15:00 h (before and after exposure), nasal lavage and blood sampling were obtained at 15:00 $\mathrm{h}$ and methacholine challenges in the morning $(08: 00 \mathrm{~h})$ the day following the exposure. Subjects whose provocative concentration causing a $20 \%$ fall in forced expiratory volume in one second (FEV1; PC20) dropped after exposure were retested the morning before being sent to the next SCB. Also, the pre-exposure forced expiratory flows were obtained to ensure that all subjects were free of airflow obstruction before going into the SCB.

\section{Lung functions}

Forced expiratory flows and volumes were obtained using a Vitalograph spirometer (Roxon, Buckingham, Buckinghamshire, UK). Complete flow curves, from which the forced vital capacity (FVC), FEV1 and the ratio FEV1/ FVC were derived. The tests were performed according to the American Thoracic Society standard procedure [20]. For the methacholine challenges only FEV1 measurements were obtained.

Standard methacholine challenge procedure as describribed by JUNIPER et al. [19] was used in this study. Briefly, doubling doses of methacholine were delivered via a calibrated Wright nebulizer (Roxon Meditech, Montréal, Quebec, Canada) and inhaled for 2 min every 5 min until there was a drop in FEV1 of at least $20 \%$ or a maximal dose of $256 \mathrm{mg} \cdot \mathrm{mL}^{-1}$ had been reached. PC20 was obtained by intrapolation on a semi-logarithmic scale.

\section{Nasal lavage}

For this sampling, after blowing and wiping their nose, the subject was instructed to occlude their posteriopharynx by positioning the tongue against the soft palate. They then tilted their head backward and $5 \mathrm{~mL}$ of $0.9 \%$ warm saline was instilled into each nostril. The saline wash was kept in the nasal cavities for $\sim 20 \mathrm{~s}$ while the subject held their breath and maintained a closed posterio-pharynx and a backward tilted head position. The subject then tilted their head forward and blew the nasal wash into a clean dry flask [22].

The nasal fluid recovered was measured and centrifuged at $500 \times g$ for $10 \mathrm{~min}$ at $4^{\circ} \mathrm{C}$. The supernatant was aliquoted and frozen at $-70^{\circ} \mathrm{C}$ for subsequent interleuki$\mathrm{n}(\mathrm{IL})-8$ analysis. The cell pellet was resuspended in $100 \mu \mathrm{L}$ to $1,000 \mu \mathrm{L}$ of Hanks' balanced saline solution (HBSS) for total cell count. Differential counts were performed on Diff-Quik stained glass cover slip slides [23]. Cell viability was verified by trypan blue exclusion.

\section{Blood samples}

Ten millilitres of heparinized venous blood was withdrawn. Total and differential counts were obtained electronically with a cell counter STKS (Courter Electronics Ltd, Hialeah, FL, USA). Another $10 \mathrm{~mL}$ of nonheparinized blood was withdrawn, allowed to clot and the serum separated by centrifugation. Serum was kept frozen at -70 until processed for the measurement of IL-6 levels.

\section{Cytokine (interleukin-8 and interleukin-6) measurements}

Levels of cytokines in nasal lavage fluids and sera were assayed by high sensitivity immunoassay kits from PerSeptive Diagnostics (Cambridge, MA, USA) for IL-8 and from R \& D Systems Inc. (Minneapolis, MN, USA) for IL-6.

\section{Statistical analysis}

The statistical method used to perform the comparisons between SCB was a one-way ANOVA with a factor representing the group effect (the comparison between the eight buildings). FEV1 and FVC were analysed for any changes between morning and afternoon. Normality and variance assumptions were tested. Posteriori comparisons were performed with Duncan's method. Significant differences between values are expressed with letters, SCB with a same letter were declared not significantly different. Relationships between parameters are expressed with the Pearson's correlation coefficients as the linearity between these parameters were observed. The results were considered significant if $p$-values were $\leq 0.05$. The data were analysed using the statistical package program SAS (SAS Institute Inc., Cary, NC, USA).

\section{Results}

\section{Building variables}

As per the experimental design there was a wide range of cleanliness scores between the eight SCB visits (table 1). Table 1 also shows that there were large differences between buildings sizes and number of pigs per operation (108-834), amounts of airborne dust $\left(2.20-5.62 \mathrm{mg} \cdot \mathrm{m}^{-3}\right)$, number of bacteria $\left(167 \times 103-929 \times 10^{3} \mathrm{CFU} \cdot \mathrm{m}^{-3}\right)$, endotoxin levels $\left(215-596 \mathrm{Eu} \cdot \mathrm{m}^{-3}\right)$, molds $(138-1805 \mathrm{CFU}$. $\left.\mathrm{m}^{-3}\right)$ and ammonia $(2.8-38.6$ parts per million (ppm).

\section{Lung functions}

Individual values for FEV1 and FVC before and after each exposure are given in figure 1. There was a significant fall in both FEV1 and FVC after the exposures to each SCB (all $\mathrm{p} \leq 0.0002$ ). There were no differences between the SCB. PC20 fell by two or more concentrations after exposure in only $3 / 64$ instances. The decreases reached statistical differences only in SCB No. $2(\mathrm{p}=$ $0.04)$. 
Table 1. - Environmental data for each of the eight swine confinement buildings visited

\begin{tabular}{lcccccrrr}
\hline $\begin{array}{l}\text { Building } \\
\text { No. }\end{array}$ & $\begin{array}{c}\text { Visual } \\
\text { score }\end{array}$ & $\begin{array}{c}\text { Building size } \\
\mathrm{m}^{3}\end{array}$ & $\begin{array}{c}\text { No. of } \\
\text { pigs }\end{array}$ & $\begin{array}{c}\text { Dust } \\
\mathrm{mg} \cdot \mathrm{M}^{3}\end{array}$ & $\begin{array}{c}\text { Bacteria } \\
\mathrm{CFU} \cdot \mathrm{m}^{3}\end{array}$ & $\begin{array}{r}\text { Endotoxins } \\
\mathrm{EU} \cdot \mathrm{m}^{3}\end{array}$ & $\begin{array}{r}\mathrm{Molds}_{\mathrm{C}} \\
\mathrm{CFU} \cdot \mathrm{m}^{3}\end{array}$ & $\begin{array}{c}\mathrm{NH}_{3} \\
\mathrm{ppm}\end{array}$ \\
\hline 1 & 1.38 & 2100 & 834 & 2.53 & 929000 & 596 & 532 & 21.83 \\
2 & 6.75 & 816 & 300 & 2.85 & 523000 & 296 & 1802 & 2.80 \\
3 & 8.25 & 523 & 350 & 4.31 & 167000 & 281 & 1805 & 8.10 \\
4 & 4.50 & 1920 & 800 & 5.62 & 481000 & 536 & 954 & 37.00 \\
5 & 1.50 & 1226 & 363 & 2.20 & 239000 & 215 & 138 & 27.00 \\
6 & 5.88 & 1223 & 108 & 3.32 & 218000 & 448 & 595 & 38.55 \\
7 & 5.38 & 799 & 364 & 3.33 & 298000 & 338 & 954 & 19.62 \\
8 & 2.37 & 1579 & 665 & 3.35 & 692000 & 523 & 282 & 10.80 \\
\hline
\end{tabular}

The values for dust, bacteria, endotoxins, and molds are the means for two visits; sample performed in triplicate at each visit. CFU: colony forming units; EU: endotoxin units; ppm: parts per million.

\section{Nasal lavage and blood analyses}

Neutrophils were significantly increased in the nasal lavages after exposure to each SCB except building No. 6 where the p-value reached 0.06 (fig. $2 \mathrm{a}$ ). White blood cells increased after each exposure ( $\mathrm{p}$-values 0.02-0.001) (fig. 2b). Nasal levels of IL-8 were highly increased after all exposures with p-values ranging 0.003-0.0001 (fig. $3 a)$. Blood levels of IL-6 were also always highly increased after exposure with p-values 0.01-0.0001 (fig. $3 b)$. There were differences between different SCB for all of these parameters (see figs. 2 and 3). The differences were not consistent but were spread out among the different SCB.

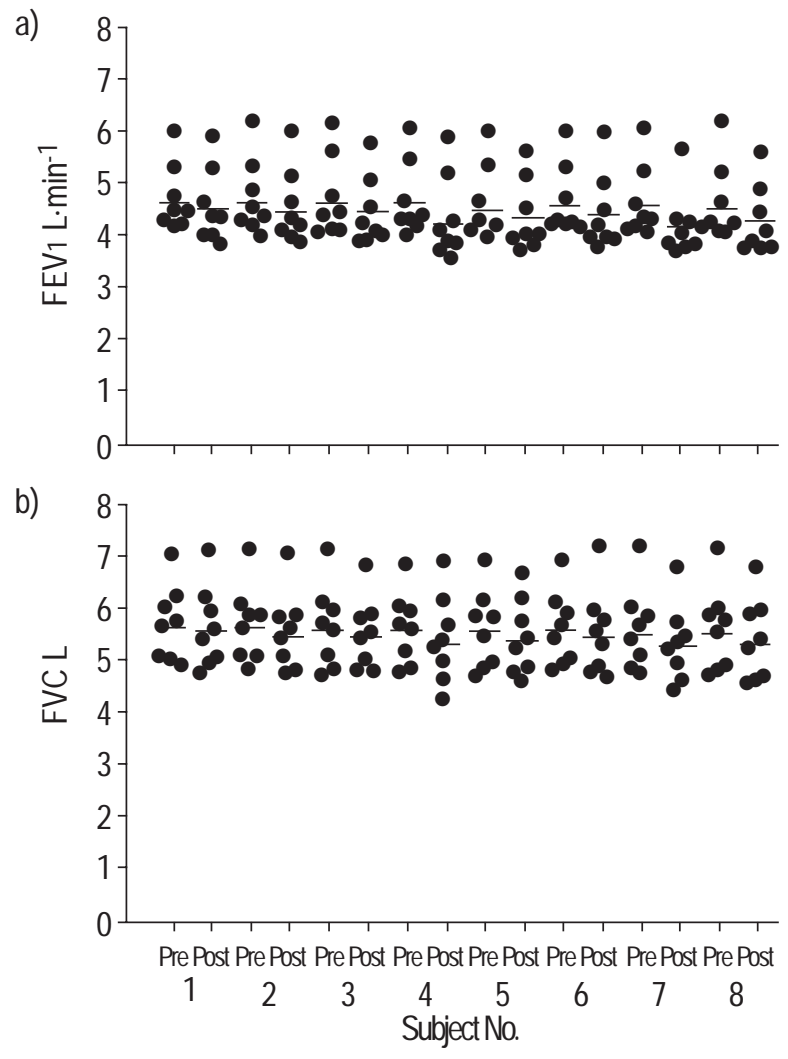

Fig. 1. - Individual values and means of a) forced expiratory volume in one second (FEV1) and b) forced expiratory vital capacity (FVC), for each of the eight subjects before and after exposure to each of the eight swine confinement buildings visited. Both parameters were similarly and significantly decreased after exposure for each of the eight buildings.

\section{Correlations between variables}

The contingency table 2 summarizes the relations between human and environmental variables. The only significant correlation between building cleanliness and environmental parameters was between $\mathrm{NH}_{3}$ and IL-6 in the serum. Since all possible pairs of variables were tested, the significance of a 0.04 p-value remains doubtful.
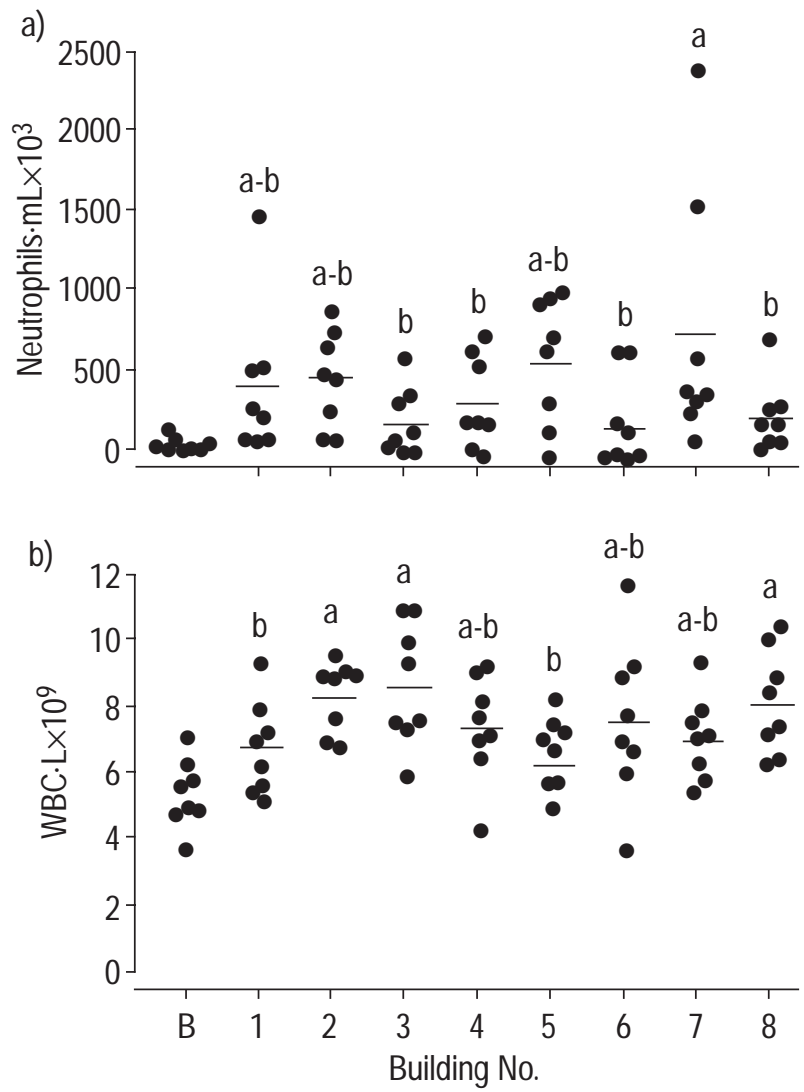

Fig. 2. - Individual values and means a) for the number of neutrophils recovered by nasal lavage and $b$ ) white blood cells (WBC). These cells increased from baseline for all but one building (No. 6) for nasal neutrophils where the p-value reached 0.06 . For clarity the significance between baseline values and exposure days are not shown on the graph. Differences between different buildings are represented by different letters above the data. In other words, all buildings with an "a" above the data are similar to each other and different from those with a " $\mathrm{b}$ " primes. For example, results of neutrophils for building 7 are different from those of buildings $3,4,6$, and 8 . B: baseline. 
a)
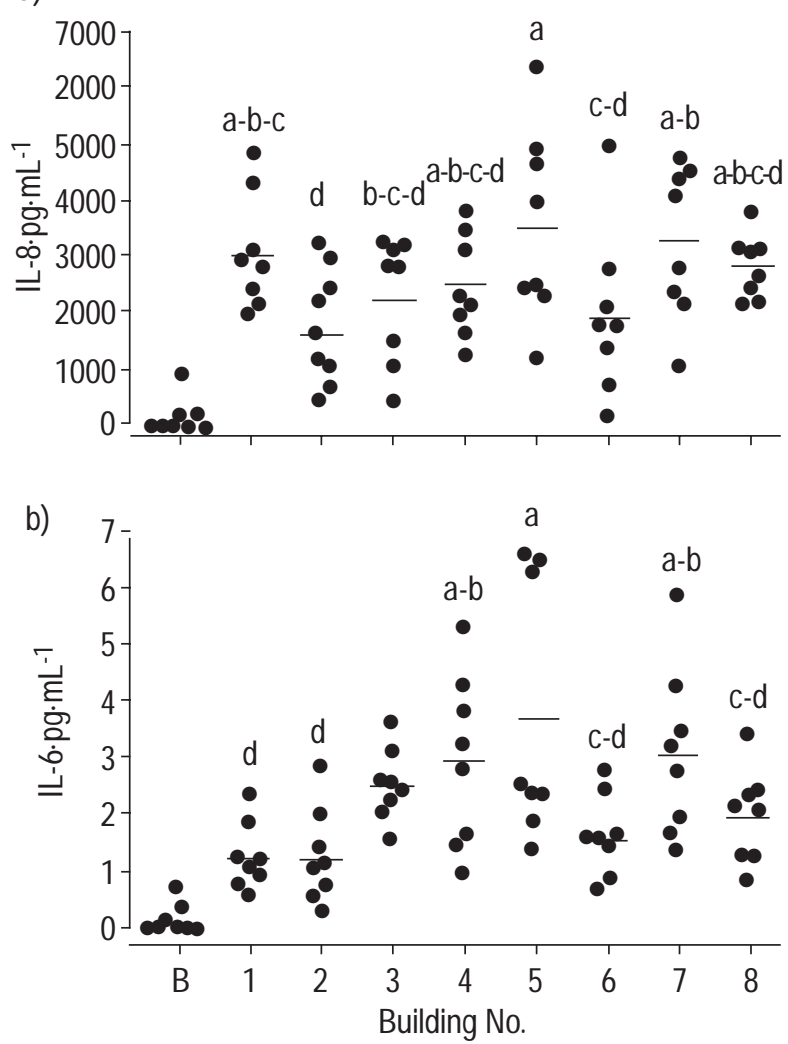

Fig. 3. - Individual values and means a) nasal levels of interleukin(IL)8 in picograms per millilitre and b) blood levels of IL-6. Highly significant and similar increases were seen after each swine building exposure. Again, as identified by different letters, some buildings had a greater effect than others. B: baseline. The differences between the buildings are indicated by the letters "a, b, c and d". Buildings marked "a" are similar to other buildings marked "a" but are different from buildings marked with any other letter. Buildings marked "a-b", for example, are similar to all buildings marked "a" and to all buildings marked "b".

\section{Discussion}

Health effects of a short term exposure of naive subjects to an SCB in this study are less striking than what has previously been described [9-12]. For example, in the current study very little and mostly nonsignificant changes in airway responsiveness were seen. These differences can be explained by the designs of the different studies. In previous reports volunteers were exposed for longer periods and performed physical activities while inside the buildings or were actively working weighing pigs $[10,12$, 13]. In the current study, subjects only spent $4 \mathrm{~h}$ inside the SCB and were not asked to do any specific activity. The exposure in this study was, however, sufficient to elicit significant effects on lung functions and induce inflammatory responses as confirmed by the increases in neutrophils and in pro-inflammatory cytokines in both the nasal wash and the peripheral blood. The light exposure in this study was purposely used in order to minimize the risk of having cumulative effects of the SCB exposures on airway functions as was previously described $[10,12]$. To further assure that there was no carry over from building to building, all subjects who had a fall in PC20 methacholine of one concentration or more were rechallenged before being exposed to the next SCB and a measure of forced expiratory flows was obtained before each exposure. In all subjects in whom control bronchoprovocation was required the $\mathrm{PC} 20$ had returned to baseline values before the re-exposure (data not shown). All FEV1 and FVC values had also returned to baseline values before each re-exposure. Previous studies have documented that the inflammatory responses to SCB exposure were of short duration $[9,11]$; these parameters were therefore not remeasured before each visit in the current study. The authors therefore show that low level exposure can be safely repeated at weekly intervals without causing alterations in lung functions and airways responsiveness.

Since the SCB were visited in random order in terms of their cleanliness and other environmental parameters the authors do not believe that tachyphylaxis to repeated exposures could explain the findings.

The changes in FEV1 and FVC, showing a decrease in the afternoon values compared to those in the morning, are probably underestimated since the normal circardian rhythms would have favoured the opposite [24]. These changes in lung function did not translate into significant differences in airway responsiveness as measured the day

Table 2. - Correlation between environmental parameters and human data

\begin{tabular}{|c|c|c|c|c|c|c|c|}
\hline & & $\Delta \mathrm{FEV}_{1}$ & $\Delta \mathrm{FVC}$ & Neutro & WBC & IL-8 & IL-6 \\
\hline \multirow[t]{2}{*}{ Visual score } & $\mathrm{R}$ & 0.23 & 0.12 & -0.18 & -0.00 & -0.46 & -0.26 \\
\hline & $\mathrm{p}$ & 0.59 & 0.77 & 0.67 & 0.99 & 0.26 & 0.55 \\
\hline \multirow[t]{2}{*}{ No. of pigs } & $\mathrm{R}$ & 0.08 & 0.08 & 0.09 & -0.61 & 0.62 & 0.21 \\
\hline & $\mathrm{p}$ & 0.85 & 0.85 & 0.84 & 0.11 & 0.10 & 0.62 \\
\hline \multirow[t]{2}{*}{ Dust } & $\mathrm{R}$ & 0.07 & -0.24 & 0.47 & -0.18 & 0.37 & 0.36 \\
\hline & $\mathrm{p}$ & 0.87 & 0.57 & 0.24 & 0.68 & 0.36 & 0.38 \\
\hline \multirow[t]{2}{*}{ Bacteria } & $\mathrm{R}$ & 0.36 & 0.40 & -0.13 & -0.43 & 0.42 & -0.35 \\
\hline & $\mathrm{p}$ & 0.38 & 0.32 & 0.76 & 0.28 & 0.30 & 0.40 \\
\hline \multirow[t]{2}{*}{ Endotoxins } & $\mathrm{R}$ & -0.01 & -0.07 & 0.25 & -0.61 & 0.72 & 0.15 \\
\hline & $\mathrm{p}$ & 0.99 & 0.87 & 0.55 & 0.11 & 0.05 & 0.71 \\
\hline \multirow[t]{2}{*}{ Molds } & $\mathrm{R}$ & 0.30 & 0.19 & 0.19 & -0.05 & -0.44 & -0.30 \\
\hline & $\mathrm{p}$ & 0.47 & 0.66 & 0.65 & 0.90 & 0.27 & 0.47 \\
\hline \multirow[t]{2}{*}{$\mathrm{NH}_{3}$} & $\mathrm{R}$ & -0.29 & -0.22 & -0.21 & 0.43 & 0.51 & 0.74 \\
\hline & $\mathrm{p}$ & 0.49 & 0.60 & 0.62 & 0.28 & 0.20 & 0.04 \\
\hline
\end{tabular}

The only significant correlation found was between the serum levels of interleukin (IL)- 6 and ammonia. $\Delta \mathrm{FEV} 1$ : change in forced expiratory volume in one second; $\triangle \mathrm{FVC}$ : forced vital capacity; Neutro: number of neutrophils in nasal lavage; WBC: white blood cells; IL-8: interleukin-8 in nasal lavage; IL-6: serum levels of IL-6; p: probability; r: relationship. Pearson's correlation coefficients were used to assess the relationships between the parameters. 
following each exposure suggesting that any inflammation or oedema were of short duration.

Of particular interest, no SCB was totally devoid of inflammatory effect. Modern technology in swine raising and cleanliness inside the buildings therefore still fails to render the air in this environment harmless to human beings. The environmental samplings and the parameters that were measured in this study were not sensitive enough to explain the differences in the effect of each building on different human variables.

In conclusion therefore: 1) repeated short term exposure to swine confinement buildings induces a reproducible, significant, and transient lung and systemic inflammatory response; 2) with participants at rest during exposure, the effects of swine building environment are transient and not cumulative and do not induce significant bronchial hyperreactivity; 3 ) visibly cleaner modern facilities are not less harmful than older ones; and 4) visual aspects, number of pigs raised and routine spot check air analysis are not useful in evaluating the potential toxic effect of inhaling swine building air.

Acknowledgements. S. Simard is credited for the statistical analysis of the data presented.

\section{References}

1. Donham KJ. Health effects from work in swine confinement buildings. Am J Ind Med 1990; 17: 17-25.

2. Holness DL, O'Blenis EL, Sass-Kortsak S, Pilger C, Nethercott JR. Respiratory effects and dust exposures in hog confinement farming. Am J Ind Med 1987; 11: 571580 .

3. Rylander R, Donham KJ, Hjort C, Brouwer R, Heederik D. Effects of exposure to dust in swine confinement buildings - a working group report. Scan J Work Environ Health 1989; 15: 309-312.

4. Dosman JA, Graham BL, Hall D, Pahwa P, McDuffie H, Ludwicz M. Respiratory symptoms and alterations in pulmonary function tests in swine producers in Saskatchewan: results of a survey of farmers. J Occup Med 1988; 30: 715-720.

5. Vohlonen I, Tupi K, Terho EO, Husman K. Prevalence and incidence of chronic bronchitis and farmer's lung with respect to the geographical location of the farm and to the work of farmers. Eur J Respir Dis 1987; 17: 37-46.

6. Rylander R, Essle N, Donham KJ. Bronchial hyperreactivity in swine and dairy farmers. Am J Ind Med 1990; 17: 66-69.

7. Zhou C, Hurst TS, Cockcroft DW, Dosman JA. Increase in airway hyperresponsiveness in swine farmers. Chest 1991; 99: 941-944.

8. Larsson K, Eklund A, Malmberg P, Belin L. Alterations in bronchoalveolar lavage fluid but not in lung functions and bronchial responsiveness in swine confinement workers. Chest 1992; 101: 767-774.

9. Larsson K, Eklund AG, Hansson L, Isaksson B, Malmberg PO. Swine dust causes intense airways inflammation in healthy subjects. Am J Respir Crit Care Med 1994; 150: 973-977.

10. Cormier Y, Duchaine C, Israël-Assayag E, Bédard G, Laviolette M, Dosmar J. Effects of swine building exposures in normal naive subjects. Eur Respir $J$ 1997; 10: $1516-1522$.

11. Wang Z, Malmberg P, Larsson P, Larsson B-M, Larsson $\mathrm{K}$. Time course of interleukin- 6 and tumor necrosis factor- $\alpha$ increase in serum following inhalation of swine dust. Am J Respir Crit Care Med 1996; 153: 147-152.

12. Malmberg P, Larsson K. Acute exposure to swine dust causes bronchial hyperresponsiveness in healthy subjects. Eur Respir J 1993; 6: 400-404.

13. Senthilselvan A, Zhang Y, Dosman JA, et al. Positive human health effect of dust suppression with canola oil in swine barns. Am J Respir Crit Care Med 1997; 156: 410 417.

14. Clark S, Rylander R, Larsson L. Airborne bacteria, endotoxin and fungi in dust in poultry and swine confinement buildings. Am Ind Hyg Assoc $J$ 1983; 44: 537-541.

15. Cormier Y, Tremblay G, Meriaux A, Brochu G, Lavoie J. Airborne microbial contents in two types of swine confinement buildings in Quebec. Am Ind Hyg Assoc J 1990; 51: 304-309.

16. Thedell TCD, Mull JC, Olenchock SA. A brief report of gram-negative bacterial endotoxin levels in airborne and settled dusts in animal confinement buildings. $\mathrm{Am} \mathrm{J}$ Indust Med 1980; 1: 3-7.

17. Donham KJ, Popendorf W, Palmgren U, Larsson L. Characterization of dust collected from swine confinement buildings. Am J Indust Med 1986; 10: 294-297.

18. Cormier Y, Laviolette M, Bédard G, Dosman J, IsraelAssayag E. Effect of route of breathing on the acute response to exposure in a swine confinement building. Am J Respir Crit Care Med 1998; 157: 1512-1521.

19. Juniper EF, Frith PA, Hargreave FE. Airway responsiveness to histamine and methacholine: relationship to minimum treatment to control symptoms of asthma. Thorax 1981; 36: 575-579.

20. Kiekhaefer MS, Donham KJ, Whitten P, Thorne PS. Cross seasonal studies of airborne microbial populations and environment in swine buildings: implications for worker and animal health. Ann Agric Environ Med 1995; 2: 37-44.

21. Anonymous. Standardization of spirometry 1994 update. Am J Respir Crit Care Med 1995; 152: 1107-1136.

22. Philip G, Baroody FM, Proud D, Naderio RM, Togias AG. The human nasal response to capsasician. J Allergy Clin Immunol 1994; 94: 1035-1045.

23. Gaultier C, Reinberg A, Girard F. Circadian rhythms in lung resistance and dynamic lung compliance. Respir Physiol 1977; 31: 169-182.

24. Laviolette M, Carreau M, Coulombe R. Bronchoalveolar lavage cell differential on microscope glass cover. Am Rev Respir Dis 1988; 138: 451-457. 